\title{
Architectural Representation of Postcolonial in New Order Era Case Study: Padepokan Pencak Silat Indonesia
}

\author{
Novianti Mawar Sari ${ }^{1}$, Kemas Ridwan Kurniawan ${ }^{1}$ \\ ${ }^{1}$ Department of Architecture, Faculty of Engineering, Universitas Indonesia, Indonesia \\ noviantimawarsari@gmail.com
}

\begin{abstract}
The aim and objective of this research are to elaborate on architectural representation in postcolonial practices in the New Order era. In this research, I describe the term postcolonial as practices followed by leadership in society. This research used a qualitative method with a historical explanation starting from the architecture itself, then to the representation, space, nationalism, and power relations. The final of this research I explain with Padepokan Pencak Silat Indonesia as a case study in the New Order era. Later in this research, I found that Padepokan Pencak Silat Indonesia proved to be an architectural representation in the New Order era with used the constructionist approach. I also mentioned in this research the importance of power relations in the development of Padepokan Pencak Silat Indonesia with the contribution of those who have the authority to run the New Order era.
\end{abstract}

(C) 2021 IJBESR. All rights reserved.

Keywords: Architecture, representation, power relations, postcolonial, new order

\section{Introduction}

The previous research that relates to this paper is based on the problem that representation is only created for the interests of leaders in a government without involving the community as recipients of representation. The problem becomes big when there is control by the leader so that people must obey and follow. The problem that occurred in postcolonial Indonesia in the New Order era is making representations of leaders' thoughts through architectural projects without seeing the influence received by society. The representation that is made becomes a problem because it is only used as a symbol of the nation to be shown to the world without thinking about its influence on the people of the nation itself.

This paper is motivated by my anxiety about architecture as a representation arena. Architecture never separates from the architect's thoughts, but in realizing a representation, it is not only influenced by the architect's role. Apart from architects, representation also involves actors, namely clients, patrons, and users. My anxiety about representation is explained by choosing postcolonial as the discussion of this paper.

Having representation for the Indonesian people makes me think that representation is very significant. I chose the New Order because there was interference from the government regarding the representation built for the Indonesian nation. Soeharto as Indonesia's second president who led the New Order era, had the power to create representation. Soeharto and his wife, Mrs. Tien, built Indonesia through traditional architecture. I want to find out more about the reasons behind the New Order's adoption of traditional concepts in architectural representation. For me, the appearance of representation is the 
result of a person's concept of thinking to represent what other people expect. If other people's expectations of the representation are fulfilled, it can be said to be a represented process. The New Order, a transition from the Old Order, quickly gave birth to new symbols to represent the nation.

I am aware that nationalism is needed in a postcolonial existence to strengthen one's nation from foreign countries. The presence of nationalism gives strength for someone to control something. Control during the New Order era gave rise to power relations in the Soeharto government, which regulated postcolonial practices. Soeharto had the power to deploy a system that would allow Indonesia to be recognized with traditional concepts. Besides, controls during the New Order era were used to organize society so that political strategies worked as expected. Establishing politics means building a government that has a center of power.

Soeharto and Mrs. Tien created a center of power as a symbol of the state by presenting Taman Mini Indonesia Indah. One of the architectural projects made in the Taman Mini Indonesia Indah area is Padepokan Pencak Silat Indonesia. Mrs. Tien sees those Indonesian traditions such as silat must be maintained by building traditional architecture to encourage people to preserve silat.

I am interested in the Padepokan Pencak Silat Indonesia as a case study. The existence of a case study made me know more about the representation process that can be realized in architectural buildings. This paper will try to explain the answers to questions related to representation in architecture in the ongoing leadership, namely in the New Order era. The questions posed are as follows: How do architectural representations in postcolonial practice the New Order era?
This discussion aims to further elaborate on architectural representation in postcolonial practices in the New Order era. The elaboration process was carried out to link the discussion of architectural representations dealing with space, nationalism, and power relations.

\section{Material and Methods}

This research will be fulfilled by using a qualitative method that I found from historical literature, starting from the architecture itself. To the representation, space, postcolonial, nationalism, power relations, and explain building tradition and Taman Mini Indonesia Indah.

\subsection{Architecture and Representation}

According to Dovey [1], architecture is how a person sees or understands the world by telling a story. One of the uses of architecture is to represent the results of concept messages in mind to represent to others. Representation is the production of meaning from concepts in our minds through language. Representation has a relationship with meaning and language towards culture. According to Hall [2], three approaches are used to connect the concept of representation with meaning and language to culture, namely the reflective, the intentional, and the constructionist. The reflective meaning is the thought that lies in objects, people, ideas, or events in the world, and language functions like a mirror, to reflect the true meaning as it already exists in the world. Intentional meaning is something that the speaker or writer uniquely controls through language. The constructionist meaning is constructed using a representation system, namely concepts and symbols.

\subsection{Architecture and Space}

Architecture has a very close relationship with space. Space is the substance of architecture with unique and distinct properties from other practices [3]. The meaning of space in 
architecture cannot be determined because it changes according to existing conditions. Architects get space already produced. Then architects can create a condition freely and based on the space they live in.

Furthermore, architecture is seen not as a practice that stands alone and manages its objects. Architecture needs to be seen as one of the many practices in which regulating space does not serve its purpose but uses power.

\subsection{Postcolonial}

Postcolonial is described as a period of history determined politically, namely from precolonial, colonial, and post-independence. According to Ashcroft [4] of Edward Said's statement, colonialism planted settlements in distant areas. Suppose it is concluded that postcolonial events occurred after the colonial period by a group that planted settlements in distant areas. In postcolonial, there are practices such as colonial discourse that leaders applied to present modern and traditional and cultural practices that began in the 18th century [5].

In the New Order era, postcolonial practice in Indonesia was led by Soeharto, the second president of the Republic of Indonesia. Although overshadowed by the modern concept, a colonial legacy, Soeharto remained in his stance, namely the traditional concept. Soeharto saw postcolonial practices as an opportunity to make Indonesia a representation.

\subsection{Nationalism}

National in a nation is not only in a form but must be a substance known as nationalism. The nation present in society needs to be maintained by the existence of nationalism. According to Anderson [6], the nation is defined as imagined as limited, imagined as sovereign, and imagined as a community.
The New Order constructed nationalism in Indonesia through traditional. For the community, leadership is essential to be seen as a figure [7]. The New Order under Soeharto's leadership put forward nationalism with a sense of love for the country. This is proven by building architectural projects that bring out elements of the traditional Indonesian nation. Soeharto controlled the country through architecture that had traditional concepts to strengthen a sense of nationalism.

\subsection{Power Relations}

The role of power is significant for a person to master the desired will. The presence of power has a different meaning for the nation. According to Anderson [8], power is explained differently from modern and traditional concepts. Power in modern Europe is an abstraction from patterns of social interaction, comes from heterogeneous sources, is not selflimiting, and is morally ambiguous. In addition, the power in the Javanese tradition has different meanings, including the following. Power is concrete. The power exists and stands in the user, not a theoretical one but a reality that has existence. Power is homogeneous. All powers have the same type and the same source. The power in the hands of individuals or groups is identical to the same power in the hands of every other group of individuals. The quantum of power in the universe is constant, even though the distribution of power in the universe varies. Power in politics has an essential role because power in one place or person requires a reduction in another. Power does not raise the question of legitimacy, so no questions such as power based on wealth are valid, and weapons are not valid.

Power relations played an essential role in the politics run by Soeharto as the leader of the New Order era. The existence of power relations by Soeharto in architectural representation can present actors, namely patrons. Patrons relate to political actors who 
contribute with their preferences [9]. Besides, Soeharto presented power through his character, which was overshadowed by the characters in the story. According to Permanasari [10] of Benedict Anderson's statement, each character from a story represents a model for self-actualization to Javanese children who imagine themselves to be knights - then adopted by the leader to associate themselves as characters from the story.

\subsection{Building Tradition}

Apart from the leadership of the Old Order, it is time for the New Order to emerge as a bearer of change for the Indonesian nation. Soeharto's New Order led to the traditional concept of inheriting existing ancestors. If explored further, it turns out that the study of traditional is an important discussion carried out by Western academics [11].

Traditional studies made the architect of the New Order era think to participate in starting to incorporate tradition into architecture so that it did not have to always dwell on modern concepts. A tradition was once 'modern' when it was discovered and continued to be transmitted to the next generation, so it was called 'tradition' [12]. Traditions do not need to be timed so that they can adapt and continue to develop.

\subsection{Taman Mini Indonesia Indah}

The idea of making Taman Mini Indonesia Indah was initiated by Mrs. Tien as the wife of President Soeharto. The construction of Taman Mini Indonesia Indah, namely in the eastern part of the Jakarta area, was based on the order of the Governor of Jakarta, Ali Sadikin. Ali Sadikin's reason was for Taman Mini Indonesia Indah to have a larger area than in the city center [13].
Taman Mini Indonesia Indah contains traditional architecture by making replicas of buildings in every remote area of Indonesia. The existence of a replica does not represent its authenticity. Still, it is hoped that it will attract the public's attention that Indonesia has a history with diverse cultures. The importance of history is as a temporality of space and its relationship between past and present [14]. If the public knows history, the perspective on interpreting a nation will be broader.

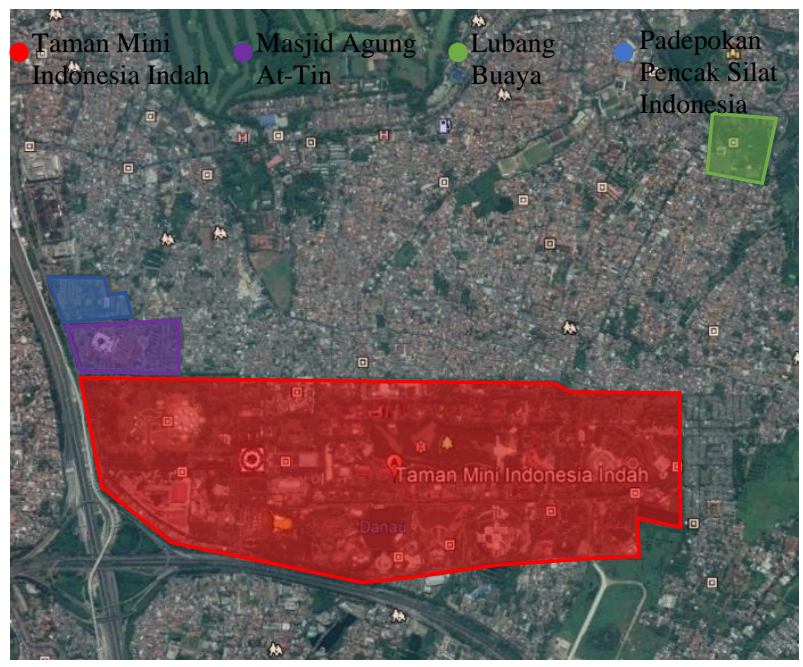

Source: (Google Earth, edited)

Figure 1: Site showing Taman Mini Indonesia Indah between Masjid Agung At-Tin, Lubang Buaya, and

Padepokan Pencak Silat Indonesia

Taman Mini Indonesia Indah is seen as a center of power surrounded by buildings created during the New Order era. Taman Mini Indonesia Indah is located between Masjid Agung At-Tin, Lubang Buaya, and Padepokan Pencak Silat Indonesia.

\section{Results and Discussions}

\section{Padepokan Pencak Silat Indonesia as Architectural Representation in the New Order Era}

\subsection{Preserving Pencak Silat as Tradition through Architecture}


In Indonesia, the word silat is inserted after the word pencak so that it is called Pencak silat. According to The Great Dictionary of Indonesian Language (KBBI), Pencak is defined as self-defense with parry skills. Meanwhile, silat means a sport that uses skill to defend oneself who can use weapons or not. So Pencak silat can be concluded as an Indonesian cultural art used for self-defense through dexterity and becomes an effort to maintain tradition.

Pencak silat is a self-defense activity that can be used as a competition to require adequate facilities. Mrs. Tien initiated a place that could facilitate Pencak silat activities through building architectural projects. In the end, there was a building called Padepokan Pencak Silat Indonesia.

\subsection{Architectural Representation of Padepokan Pencak Silat Indonesia}

This sub-section will explain the constructionist and traditional architecture.

\subsubsection{The Constructionist}

Referring to Stuart Hall's theory, the representation used at Padepokan Pencak Silat Indonesia is the constructionist. The constructionist has the meaning of construction utilizing a representation system, namely concepts and symbols. The reason Padepokan Pencak Silat Indonesia was constructed is that it fits the cultural development of Taman Mini Indonesia Indah. According to Tongam Sinaga, the culture of inheriting the traditions that Taman Mini Indonesia Indah already had was developed again by constructing the Padepokan Pencak Silat Indonesia to inherit Pencak silat tradition.

According to the Javanese - Indonesian Language Dictionary I, the word padepokan comes from the word dhepok, which means house (dwelling), dhepokan which means sitting on the ground, and dheprok / ndeprok which means sitting anywhere. According to the Kawi - Indonesian Dictionary, padepokan comes from the Sundanese word depok, which means a place of meditation. Then according to The Great Dictionary of Indonesian Language, padepokan comes from the word depok, which means to sit on the floor or a mat with both legs folded to the left or right.

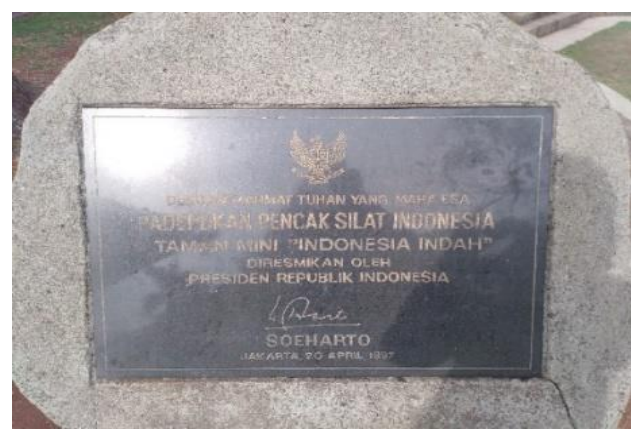

Source: (Personal documentation, 2019)

Figure 2: The inauguration stone of Padepokan Pencak Silat Indonesia signed by Soeharto

Padepokan Pencak Silat Indonesia is located in Taman Mini Indonesia Indah area with an address at Jl. Raya TMII I, East Jakarta. Mrs. Tien Soeharto initiated the idea for the construction of Padepokan Pencak Silat Indonesia as the First Lady. The inauguration of Padepokan Pencak Silat Indonesia was signed by Soeharto on April 20, 1997. According to Bawor Wulung, the purpose of establishing Padepokan Pencak Silat Indonesia was as a center for the concentration of pencak silat activities in Indonesia. 


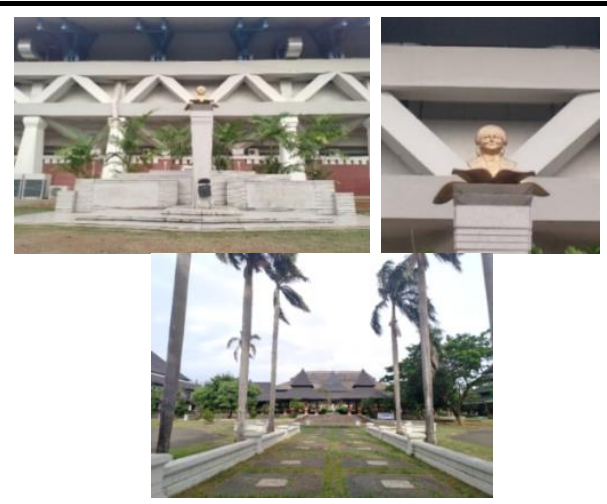

Source: (Personal documentation, 2019)

Figure 3: The monument dedicated to Tien Soeharto (above) and the courtyard area towards the main building of Padepokan Pencak Silat Indonesia (below)

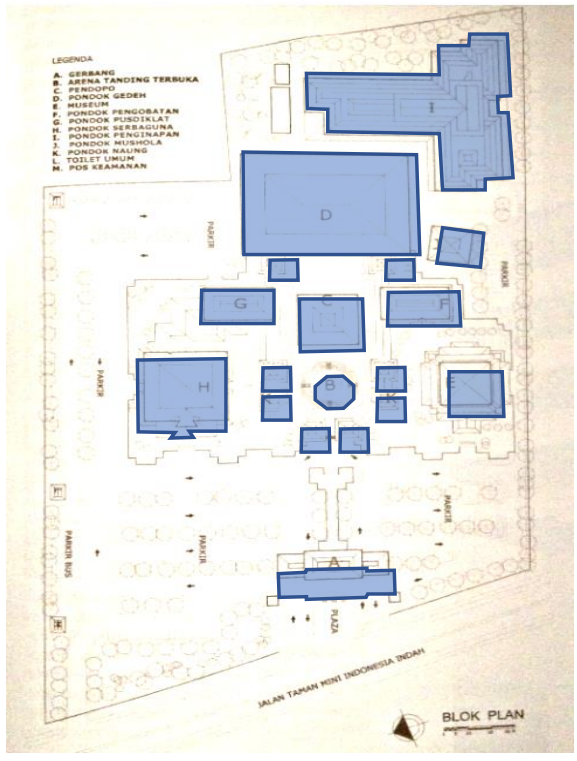

Source: (Arsitektur 4D: 72 Karya + 10 Sayembara Arsitektur Universitas Indonesia, edited)

Figure 4: Block Plan of the Padepokan Pencak Silat Indonesia

Padepokan Pencak Silat Indonesia has a land area of $52.290 \mathrm{~m}^{2}$ with a building area of 21.110 $\mathrm{m}^{2}$ [15]. Placement of the site plan next to Masjid Agung At-Tin. Padepokan Pencak Silat Indonesia consists of Pondok Serbaguna (multipurpose room), Museum, Library, Pendopo (pavilion), Pondok Gedeh (closed competition arena), Arena Tanding Terbuka (open competition arena), Pondok Mushola (prayer room), and Pondok Penginapan (hotel).
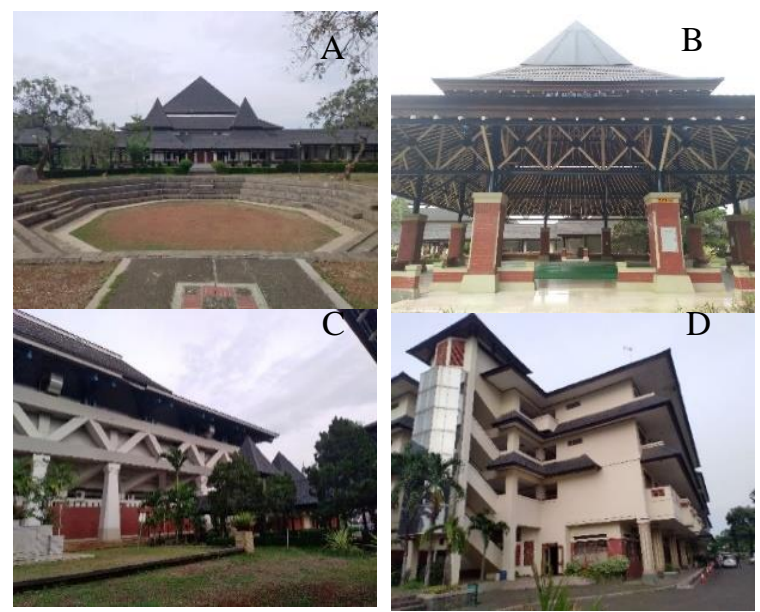

Source: (Personal documentation, 2019)

Figure 5: Arena Tanding Terbuka with background of Pondok Serbaguna (A), Pendopo (B), Pondok Gedeh (C), and Pondok Penginapan (D)

\subsubsection{Traditional Architecture}

Padepokan Pencak Silat Indonesia uses the concept of traditional architectural buildings by presenting a symbol. The entire building is made in the same language that is recognized as traditional architecture. The traditional architecture used by Padepokan Pencak Silat Indonesia is limasan (pyramid) type. The limasan type is seen because it has a longer ridge. The long ridge makes the roof plate also elongated [16].

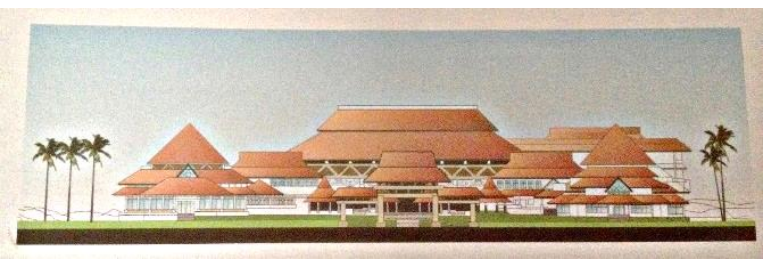

Source: (Arsitektur 4D: 72 Karya + 10 Sayembara Arsitektur Universitas Indonesia)

Figure 6: Elevation of the Padepokan Pencak Silat Indonesia 
Padepokan Pencak Silat Indonesia was carried out by architect Bayu Pradhana, Yayat Priyatmoko, and PT Aspac Mitra Consultindo team with the design starting in 1991. The model below explains the existence of Padepokan Pencak Silat Indonesia. From a model, it can be seen that Padepokan Pencak Silat Indonesia applies traditional architectural buildings. The reason that can be given is that it is clearly illustrated the shape of the roof of the building. Besides, it can be explained about the presence of green open spaces and coconut trees that grow around the entrance area of Padepokan Pencak Silat, Indonesia.

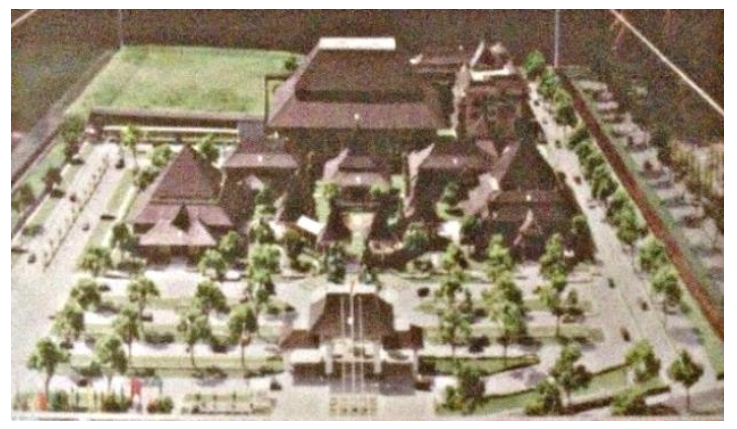

Source: (Arsitektur 4D: 72 Karya + 10 Sayembara Arsitektur Universitas Indonesia)

Figure 7: Model of the Padepokan Pencak Silat Indonesia

The picture below shows the gate that welcomes the people who come so that it is the most important part in describing the overall condition of the building.

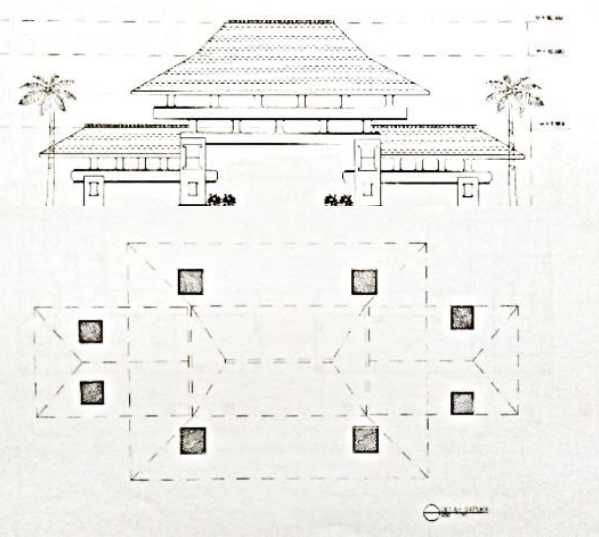

Source: (Padepokan Pencak Silat Indonesia Library) Figure 8: Front view and plan of the gate
The gate that was built has one main roof that is placed in the middle and the highest. While the other two roofs are on the right and left. The roof is used using a limasan type with a long ridge that can show a welcome gate for Padepokan Pencak Silat Indonesia.

\subsection{Power Relations in the Development of Padepokan Pencak Silat Indonesia}

This sub-section will explain about Ikatan Pencak Silat Indonesia, Soeharto dynasty, architectural project with land acquisition and removal of Very High Voltage Power Lines, and theater society in the New Order era.

\subsubsection{Ikatan Pencak Silat Indonesia}

Pencak silat is a tradition as part of Indonesia's cultural heritage. Pencak silat groups in Indonesia were united with a larger group called the Ikatan Pencak Silat Indonesia (Pencak Silat Indonesia Association - IPSI) since 1973. Eddie Marzuki Nalapraya as chairman of Ikatan Pencak Silat Indonesia (1981-2003) and also served as Deputy Governor of DKI Jakarta (1984-1987) has an important role in Padepokan Pencak Silat Indonesia. Eddie Nalapraya is concerned about the lack of attention to facilities for pencak silat, even though in the New Order, pencak silat has started to go global. 


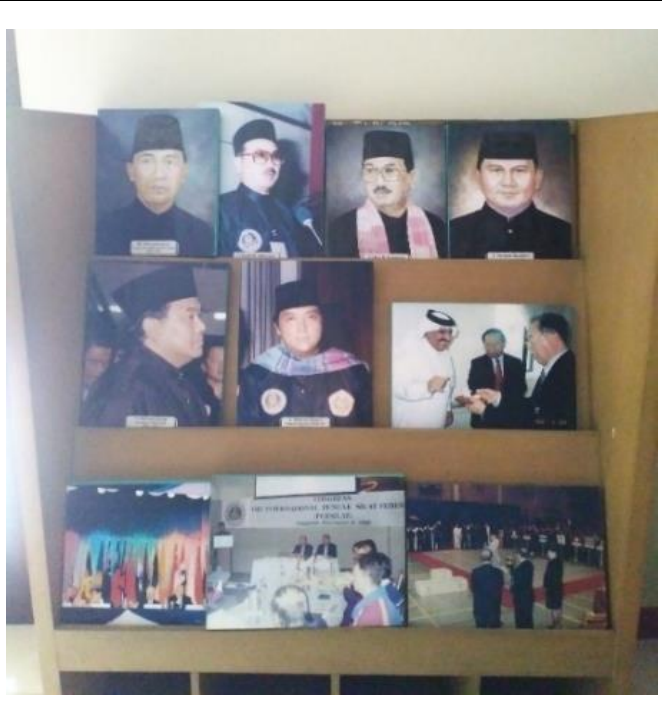

Source: (Padepokan Pencak Silat Indonesia Library) Figure 9: The row of photos of the figures who served as Chairman of Ikatan Pencak Silat Indonesia

Eddie's position as an important figure in pencak silat has enough influence to talk to Mrs. Tien about the issue of pencak silat. Not only Eddie Nalapraya, but the important pencak silat figure for the Padepokan Pencak Silat Indonesia is also Prabowo Subianto. Prabowo and Eddie gathered to discuss the place for pesilat (silat player) to Mrs. Tien.

\subsubsection{Soeharto Dynasty}

Soeharto had a family that was included in the New Order government. Soeharto's power relations were also handed over by his children and grandchildren. The New Order work program which involved Soeharto's own family could be said to be a dynasty. The power relations passed on by the lineage of a family can show society that the government is getting stronger.

In the case of Padepokan Pencak Silat Indonesia, the construction that occurred was also managed by the Soeharto dynasty. Soeharto and Mrs. Tien had Bambang Trihatmodjo as their 3rd child and Prabowo Subianto as their son-in-law. Bambang and Prabowo were given the power to manage the development of Padepokan Pencak Silat
Indonesia. As Indonesian pencak silat figures, Bambang and Prabowo together with Eddie helped Mrs. Tien so that the proposal for Padepokan Pencak Silat Indonesia could be approved in front of President Soeharto.

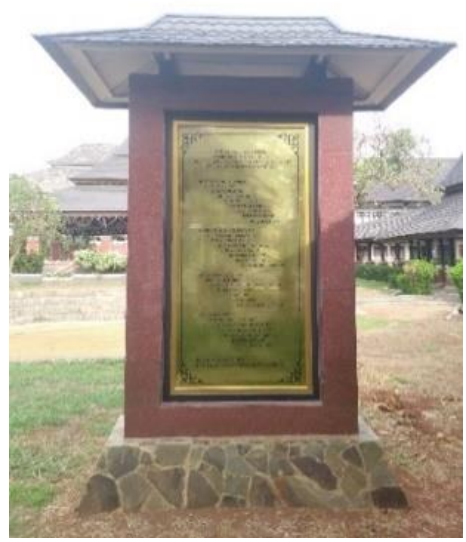

Source: (Personal documentation, 2019)

Figure 10: Inscription of the names of those who participated in the construction of the Padepokan Pencak Silat Indonesia

\subsubsection{Architectural Project with Land Acquisition and Removal of Very High Voltage Power Lines}

The construction of Padepokan Pencak Silat Indonesia was influenced by designs made by architects. According to Bayu Pradhana, the design of Padepokan Pencak Silat Indonesia is entirely the creativity of the architect. Before designing, the architect analyzes the site context in the field. On the land for the building of Padepokan Pencak Silat Indonesia, it turns out to be a settlement owned by residents. The existence of a resident's house requires Mrs. Tien to acquire the land. 


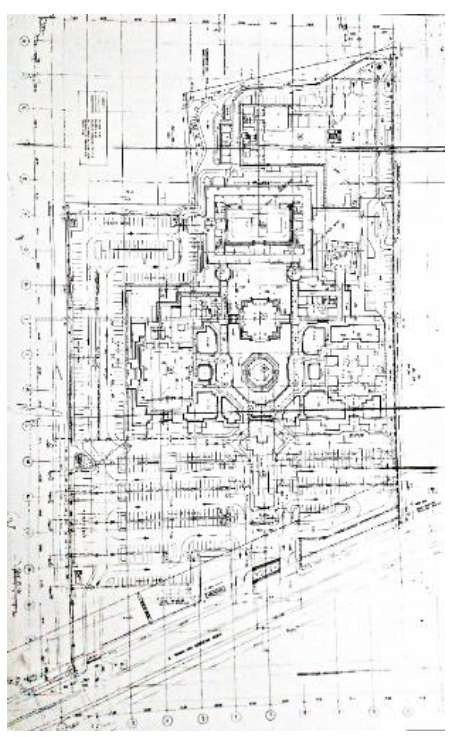

Source: (Padepokan Pencak Silat Indonesia Library) Figure 11: Site Plan of the Padepokan Pencak Silat Indonesia

The development problem is not only in acquiring land for residents' houses but also in the placement of Very High Voltage Power Lines (Saluran Udara Tegangan Ekstra Tinggi) located in the land area. The architects suggested that Very High Voltage Power Lines should be removed as this could become a barrier to the design. However, because of the power of Mrs. Tien, Very High Voltage Power Lines can be moved by Perusahaan Listrik Negara (State Electricity Enterprise - PLN) so that the construction of Padepokan Pencak Silat Indonesia can begin.

\subsubsection{Theater Society in the New Order Era}

The construction of Padepokan Pencak Silat Indonesia was inaugurated by President Soeharto in 1997. The inauguration ceremony was held in a pencak silat competition arena called Pondok Gedeh. The public witnessed the inauguration of Padepokan Pencak Silat Indonesia which was broadcast live on television. The public can see Soeharto's power relations in the construction of Padepokan Pencak Silat Indonesia answering the preservation of tradition. The inauguration that was broadcast live on television is a concept of the theater society.

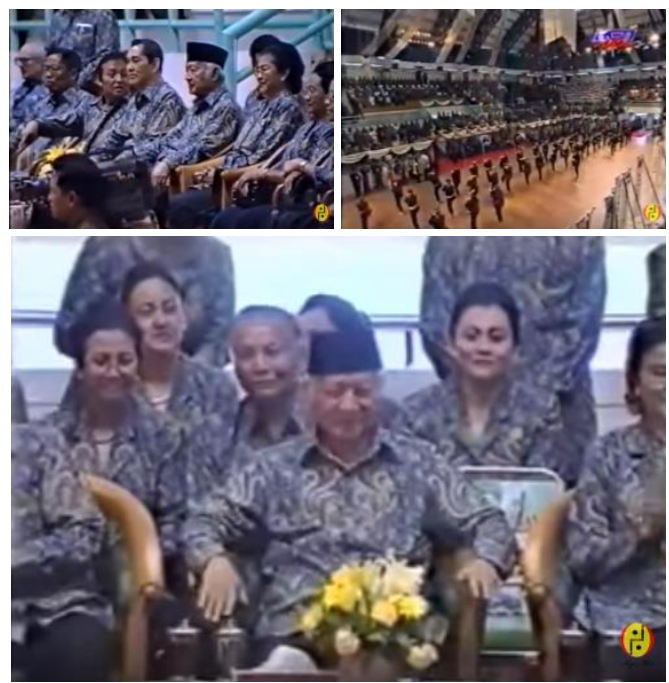

Source:https://www.youtube.com/watch?v=LdnWtQ2K LtM

Figure 12: Soeharto attended the inauguration of the Padepokan Pencak Silat Indonesia which was broadcast live to the public via television on RCTI

The theater is defined as a performance or ceremony watched by the public. Among the actors involved in theater are leaders, directors, supporting actors, stage crews, and audiences [17]. The inauguration of Padepokan Pencak Silat Indonesia, which was held with a theater, showed that Soeharto had a role as a leader.

\section{Conclusion}

Based on my explanation for Padepokan Pencak Silat Indonesia, the postcolonial architectural representation of Padepokan Pencak Silat Indonesia is through a constructionist approach by inheriting traditional architectural traditions. Based on Stuart Hall's theory, Padepokan Pencak Silat Indonesia uses a constructionist. The reason is that the meaning of architectural representation from Padepokan Pencak Silat Indonesia is a traditional architectural concept and represents Indonesia. Padepokan Pencak Silat Indonesia represents Indonesia with evidence of traditional elements incorporated into 
architectural buildings. Tradition in an architectural representation was carried out in the New Order regime to ensure the government's stability.

Power relations played a primary role in the development process involving dominant figures in the New Order era. The power relations that existed in the New Order era were homogeneous, meaning they had the same source from one group to another. The construction of Padepokan Pencak Silat Indonesia took place under the power of Soeharto and Mrs. Tien. Padepokan Pencak Silat Indonesia is in harmony with the cultural development of Taman Mini Indonesia Indah. The role of silat figures was important in conveying Mrs. Tien's aspirations so that President Soeharto approved it. Soeharto's dynasty managed the construction of Padepokan Pencak Silat Indonesia, so it is not surprising that all control was held under the New Order regime. The architectural project of Padepokan Pencak Silat Indonesia involves power relations to clear obstacles on the site, such as land acquisition and removal of Very High Voltage Power Lines. The transfer process was not a problem for Soeharto and Mrs. Tien, thus showing that power relations were very dominant during the development process. Then the inauguration of Padepokan Pencak Silat Indonesia by Soeharto broadcast on television was part of the concept of theater society.

\section{Acknowledgement}

This paper is a revised version of my Undergraduate thesis under the supervision of Prof. Kemas Ridwan Kurniawan, S.T., M.Sc., Ph.D. I would like to thank Mohammad Nanda Widyarta, B.Arch., M.Arch. and Mush'ab 'Abdu Asy Syahid, S.Ars., M.Ars. as the examiners during my thesis defense who gave a lot of input to make this paper better. Bayu Pradhana as the architect of Padepokan Pencak Silat Indonesia, who allowed me to interview.
Tongam Sinaga and Bawor Wulung, as part of Padepokan Pencak Silat Indonesia in providing accurate data.

\section{References}

[1] Dovey K, Framing Places: Mediating Power in Built Form, London and New York: Routledge; 1999, p. 30.

[2] Hall S, Representations: Cultural Representations and Signifying Practices, Milton Keynes: The Open University; 1997, p. 24.

[3] Forty A, "Space." Words and Buildings: A Vocabulary of Modern Architecture, London: Thames \& Hudson; 2000, p. 256.

[4] Ashcroft B, Griffiths G, and Tiffin H, Post-Colonial Studies: The Key Concepts, $2^{\text {nd }}$ edition, USA and Canada: Routledge; 2007, p. 40.

[5] Nalbantoglu GB and Thai WC (eds.), Postcolonial Space(s), New York: Princeton Architectural Press; 1997 , p. 8.

[6] Anderson B, Imagined Communities: Reflections on the Origin and Spread of Nationalism, revised edition, London and New York; 2006, p. 7.

[7] Kurniawan KR, "The Social Development and Revitalisation Process of The Heritage Town of Muntok in West Bangka." International Journal of Built Environment and Scientific Research, vol. 01 no. 02, Jakarta: Department of Architecture UMJ; 2017, p. 96.

[8] Anderson B, Language and Power: Exploring Political Cultures in Indonesia, Ithaca: Cornell University Press; 1990, p. 21-22.

[9] Syahid MAA, "Translating Modern Ideas into Postcolonial Mosque Architecture in Indonesia." International Journal of Built Environment and Scientific Research, vol. 02 no. 01, Jakarta: Department of Architecture UMJ; 2018, p. 41.

[10] Permanasari E, "Culture and Myth in Socio-Spatial Practice." Mark Gillem (ed.) Traditional Dwellings and Settlements Working Paper Series, vol. 250, Berkeley: IASTE; 2012, p. 4.

[11] Kusno A, translated by Saraswati T, Di Balik Pascakolonial: Arsitektur, Ruang Kota, dan Budaya Politik di Indonesia, Surabaya: Airlangga University Press; 2007, p. 92.

[12] Kusno A, ed., "Postcolonial Traditionality: Gunawan Tjahjono \& Josef Prijotomo." Inaugural Speeches in the Built Environment: Global and Contextualised, Issue 2, Delft: TU Delft Open; 2017, p. 26.

[13] Lukito YN, Exhibiting Modernity and Indonesian Vernacular Architecture: Hybrid Architecture at Pasar Gambir of Batavia, the 1931 Paris International Colonial Exhibition and Taman Mini Indonesia Indah, Wiesbaden: Springer VS; 2016, p. 130. 
International Journal of Built Environment and Scientific Research p-issn: 2581-1347 | e-issn: 2580-2607 | Pg. 85 - 96

[14] Kurniawan KR, Postcolonial History of [16] Prijotomo J, Petungan: Sistem Ukuran dalam Architecture and Urbanism: Power and Space of Indonesian Tin Mining in Bangka Island, U.K.: VDM Verlag Dr. Muller GmbH \& Co. KG; 2011, p. 117.

[15] Tjahjono G, et. al. "Bayu Pradhana: Padepokan Nasional Pencak Silat." Arsitektur 4D: 72 Karya + 10 Sayembara Arsitektur Universitas Indonesia, Jakarta: PT Gramedia Pustaka Utama; 2011, p. 99. Arsitektur Jawa, Yogyakarta: Gadjah Mada University Press; 1995, p. 8.

[17] Geertz C, Negara: The Theatre State in NineteenthCentury Bali, New Jersey: Princeton University Press; 1980, p. 13. 
(This page is intentionally left blank) 